\title{
New record of Copidognathus andhraensis (Acari: Halacaridae) from the west coast of India, Arabian Sea
}

\author{
TAPAS CHATTERJEE
}

Crescent International School, Bario, Govindpur, Dhanbad 828109, Jharkhand, India, e-mail: drtchatterjee@yahoo.co.in

\begin{abstract}
Keywords Copidognathus andhraensis, West coast India, Arabian Sea
Abstract Copidognathus andhraensis Chatterjee, Annapurna \& Chang, 2004 is reported here from Anjuna beach, Goa, west coast of India (Arabian Sea) among algal sediment. This is the first report of this species from west coast of India and also from the Arabian Sea.
\end{abstract}

Nowe stwierdzenie Copidognathus andhraensis (Acari: Halacaridae) z Zachodniego wybrzeża Indii, Morze Arabskie

Słowa kluczowe Copidognathus andhraensis, zachodnie wybrzeż Indii, Morze Arabskie

Streszczenie Copidognathus andhraensis został stwierdzony na plaży Anjuna, (Goa, zachodnie wybrzeża Indii, Morze Arabskie) pośród osadów alg. Jest to pierwsze stwierdzenie tego gatunku z zachodniego wybrzeża Indii, a także z Morza Arabskiego.

\section{Introduction}

Copidognathus is most species rich genus in the family Halacaridae (see Bartsch, 2009). In India, species of the genus Copidognathus were recorded from Chilka lagoon, Odisha, east coast of India (Chatterjee, 1991a; Chatterjee, Sarma, 1993); Visakhapatnam, Andhra Pradesh, east coast of India (Chatterjee, 1991b, Chatterjee, Annapurna, 2002, 2003; Chatterjee et al., 2003, 2004); Kerala, west coast of India (Chatterjee, Sarma, 1993; Chatterjee, 2000); Maharastra, west coast of India (Chatterjee, Chang, 2004); Goa, west coast of India (Chatterjee, Guru, 2011; Chatterjee, 2015) and Andaman \& Nicobar Islands (Chatterjee, 1991c, 1992, 1995, 1996, 1997, 1999a,b; Chatterjee, De Troch, 2003; Sarma, Chatterjee, 1991; Chatterjee, Guru, 2013).

Copidognathus andhraensis was first described from Palm beach, Visakhapatnam, Andhra Pradesh, east coast of India among phytal samples (macroalgae) (Chatterjee et al., 2004). This species was also recorded from Singapore among colonies of Bryozoa (Bartsch, 2013).

The specimen of $C$. andhraensis used in the present study was collected from Goa, India, among macro algae, makes it the first recording of the species from west coast of India and also first report from the Arabian Sea. 


\section{Material and methods}

One male among mixed macro algae growing on rocky coast of Anjuna beach (Lat. $15^{\circ} 34^{\prime}$ 58" N; Long. 73 44' 28.54" E), Goa, west coast of India, 20th May 2011, coll. T. Chatterjee.

After preliminary observation specimen was processed for SEM study.

Specimen for scanning electron microscopy (SEM) was prefixed overnight at $4^{\circ} \mathrm{C}$ in $2.5 \%$ glutaraldehyde, followed by post fixation in $2 \%$ cold osmium tetroxide. After dehydration through a graded series of ethanol (50-100\% at 10\% interval) for 30 minutes each, the material was critical point dried, and coated with a platinum-palladium mix in a high evaporator, and then examined with a scanning electron microscope.

The following abbreviations are used in the text and figure legends: AD, anterior dorsal plate; AE, anterior epimeral plate; ds, dorsal setae 1-2 on the idiosoma; GA, genitoanal plate; GO, genital opening; OC, ocular plate(s); PAS, parambulacral seta(e); PGS, Perigenital setae.

\section{Results and Discussion}

Copidognathus andhraensis Chatterjee, Annapurna \& Chang 2004

Copidognathus andhraensis - Chatterjee et al. 2004, 75-78, Figs. 1A-G, 2A-D.

Copidognathus andhraensis - Bartsch 2013, 111-119, Figs. 1-20.

Brief Description: Small median elevated area (areola) on AD; setae ds 1 on posterior side of median areola and pair of gland pores on anterior side of this areola. Distance between two gland pores almost (or more than) twice than that of two setae of $\mathrm{ds}_{1}$. A pair of middle costae restricted to posterior third of the posterior dorsal plate. Anterior cornea on OC large, posterior cornea subdivided into two small corneae; $\mathrm{ds}_{2}$ on near anteromedian corner of OC. Pair of oblong punctate areolae present within area representing first pair of epimera on AE (Figure 1B). Magnified view of epimeral pore on AE shown in Figure 1C. In male paragenital areolae enlarged anteriorly and occupying almost entire length of GA, but not touching anterior end of GA. In present male, distance between anterior end of GO and that of GA equaling about 1.2 times of GO length (Figure 1A). In male about 40 PGS present, about 5 pairs close to and about 30setae in a wide ring around GO (Figures 1A, D). Legs slender (Figure 1A). Pectinate setae on leg I-IV: 0-2-1-0 (Figures 2A, B). Tarsus I with 2 doublets eupathid PAS. Tarsus II with 2 singlet eupathid PAS. Paired claws II to IV with pectines extending along inner flank of claws (Figures 2C-E).

Distribution: Indian Ocean - Andhra Pradesh, east coast of India, Bay of Bengal (Chatterjee et al 2004); Goa, west coast of India, Arabian Sea (Present report); Pacific Ocean - Singapore (Bartsch, 2013).

Remarks: Bartsch (2013) commented about pair of gland pores on the AD and pair of ds shown in Fig 1B of Chatterjee (2004) 'distance between pores about the same as between the pair of setae', but in Fig 1B of Chatterjee (2004) and in present specimen showing that the distance between two gland pores more than twice than that between two setae of $\mathrm{ds}_{1}$ as found in Singapore specimens. The position of $\mathrm{ds}_{2}$ in the present study is found near anteromedian corner of OC similar with Bartsch (2013). Claws also found similar with Singapore specimens in present study.

There are many natural species groups in the genus Copidognathus. One of these groups is the 'tricorneatus' group. At present, 14 species of this species group have been recorded. Copidognathus andhraensis Chatterjee, Annapurna \& Chang has been reported among phytal algal samples from Andhra Pradesh, east coast of India (Chatterjee et al., 2004), among algal 



Figure 1. Copidognathus andhraensis Chatterjee, Annapurna and Chang, 2004 male. A. Idiosoma, ventral; B. Ventral areola on AE; C. Magnified view of epimeral pore on AE; D. GO. (Scale bars: A, B, D = $10 \mu \mathrm{m}$, $\mathrm{C}=1 \mu \mathrm{m})$

sediments from Anjuna beach Goa, west coast of India (present report) and among bryozoa from Singapore (Bartsch, 2013). Copidognathus dictyotellus Bartsch was reported among corals, algae and sponges in Rottnest Island, Western Australia (Bartsch, 1997, 1998). Bartsch (1993) reported C. dictyotus Bartsch from Babi Besar Island, Malaysia, South China Sea, among dead coral blocks and calcareous algae, in and below the tidal range. The species $C$. hummelincki (Viets) was reported from Bonaire and Aruba, Caribbean Sea (Viets, 1936) and also among algae Halemida from Florida, USA (Newell, 1947). Copidognathus kagamili Newell was reported in northeastern Pacific, Aleutian Islands from boulders covered with corals, sponges, and hydrozoans at about $75 \mathrm{~m}$ depth (Newell, 1950). Otto (2001) reported C. leptoporus Otto from Great Barrier Reef in northeastern Australia among coarse sand, coralline algae, and hydroids at $0.5 \mathrm{~m}$ to $9 \mathrm{~m}$ depth. Otto (2001) also reported C. megaloporus Otto, 2001 from Great Barrier Reef in northeastern Australia (Otto, 2001). Copidognathus longipes Bartsch was recorded from northwestern Atlantic (Josephine Bank), taken from a depth of 210-240 m (Bartsch, 1973). Copidognathus mucronatus Viets was reported from Black Sea (Viets, 1928; Bartsch, 1997, 2001) taken from Phyllophora, Rhodophyta (Viets, 1928). Copidognathus quadricostatus (Trouessart) and C. trouessarti (Voinov) were reported from northeastern Atlantic and Mediterranean (Trouessart, 1894; Voinov, 1896; Bartsch,1991, 1997).The species C. quadricostatus and C. trouessarti often found together amongst sublittoral bryozoans and barnacles (Bartsch, 1997). Copidognathus spophaie Pepato 


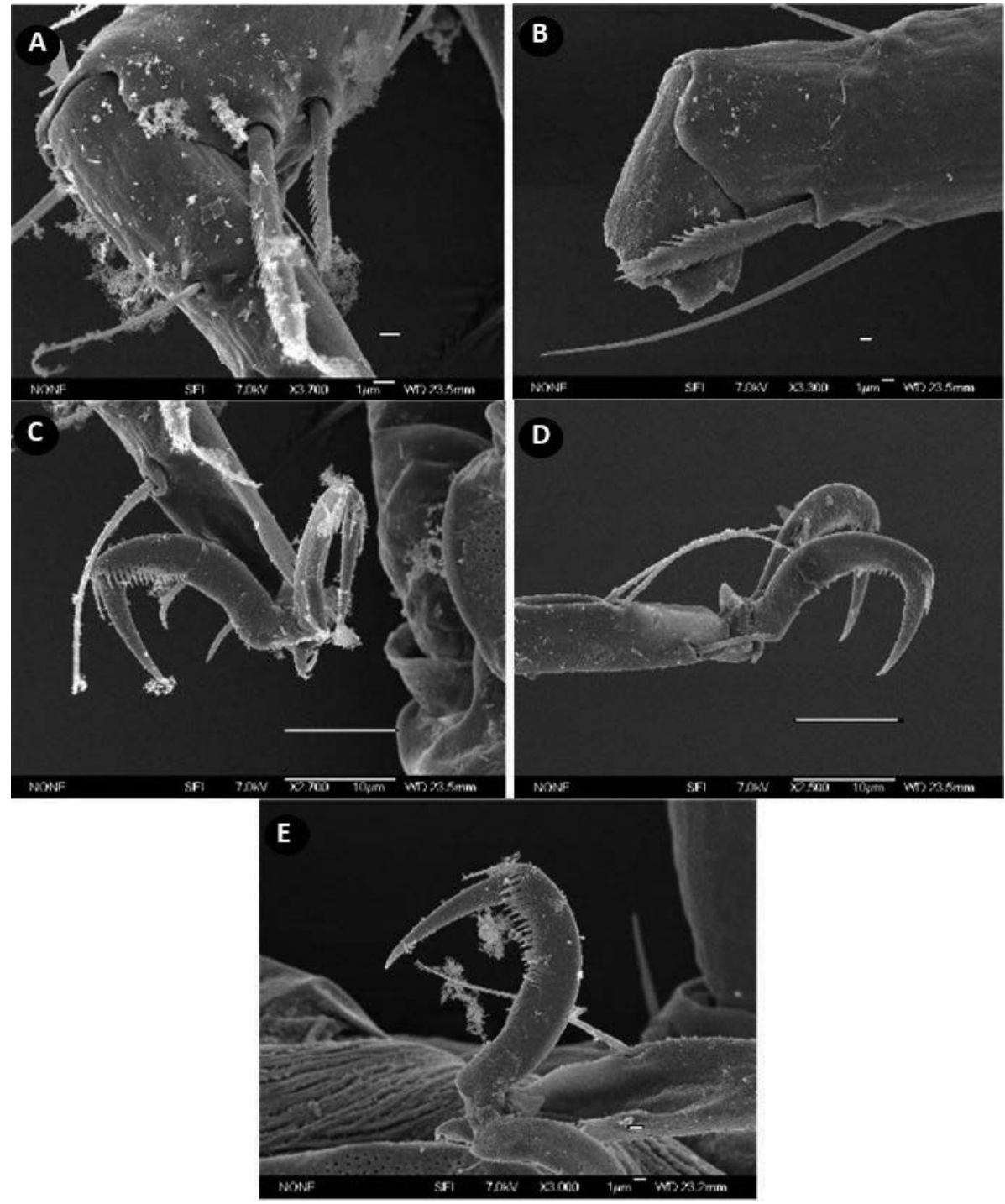

Figure 2. Copidognathus andhraensis Chatterjee, Annapurna and Chang, 2004 male. A. Part of tibia II showing pectinate setae; B. Part of tibia III showing pectinate seta; C. Part of tarsus II showing claws; D. part of tarsus III; E. Claw of tarsus IV. (Scale bars: A, B, E $=1 \mu \mathrm{m} ; \mathrm{C}, \mathrm{D}=10 \mu \mathrm{m}$ )

\& Tiago was reported among Sargassum cymosum from intertidal rocky shore at Lázaro Beach, Brazil (Pepato, Tiago, 2005). Copidognathus tricorneatus was reported from eastern Australia, Sydney, from a substratum with corals and sponges (Viets, 1938; Bartsch, 1997). Copidognathus xaixaiensis Proches was reported from the middle littoral rocks on the breakwater wall facing the resort in Xai-Xai, Mozambique (Proches, 2002). Three species: C. andhraensis, C. dictyotellus, and $C$. xaixaiensis are known from Indian Ocean region. 


\section{Acknowledgement}

Thanks are due to Dr. Martin V. Sorensen, Natural History Museum of Denmark, University of Copenhagen, Denmark for making the SEM photographs of these mites.

\section{References}

Bartsch, I. (1973). Halacaridae (Acari) von der Josephinebank und der großen Meteorbank aus dem östlichen Nordatlantik. I. Die Halacaridae aus den Schleppnetzproben. Meteor Forschungs-Ergebnisse, Reihe D, 13, 37-46.

Bartsch, I. (1991). On the identity of some North Atlantic halacarid species (Acari). Journal of Natural History, 25, 1339-1353.

Bartsch, I. (1993). Halacaridae (Acari) von Malaysia. Beschreibung von drei Arten der Gattung Copidognathus. Entomologische Mitteilungen aus dem Zoologischen Museum Hamburg, 11, 45-58.

Bartsch, I. (1997). A new species of the Copidognathus tricorneatus group (Acari: Halacaridae) from Western Australia with a review of this species-group. Species Diversity, 2, 155-166.

Bartsch, I. (1998). Copidognathus dictyotellus nom. nov. replacement name for a homonym (Acari: Halacaridae). Species Diversity, 3, 317-318.

Bartsch, I. (2001). Black Sea Copidognathinae (Arachnida, Acari, Halacaridae): A review. Mitteilungen aus dem Museum für Naturkunde in Berlin, Zoologische Reihe, 77, 247-275.

Bartsch, I. (2009). Checklist of marine and freshwater halacarid mite genera and species (Halacaridae: Acari) with notes on synonyms, habitats, distribution and descriptions of the taxa. Zootaxa, 1998, $1-170$.

Bartsch, I. (2013). Copidognathus andhraensis (Halacaridae: Acari), a new record from Singapore, supplemental description and notes on the habitat. Entomologische Mitteilungen aus dem Zoologischen Museum Hamburg, 16 (190), 111-119.

Chatterjee, T. (1991a). A new species of Copidognathus (Halacaridae: Acari) from Chilka lagoon, Bay of Bengal. Journal of the Bombay Natural History Society, 88 (3), 406-409.

Chatterjee, T. (1991b). Copidognathus gitae, a new species of Halacaridae (Acari) from Visakhapatnam Coast, Bay of Bengal. Journal of the Bombay Natural History Society, 88 (2), 272-275.

Chatterjee, T. (1991c). Copidognathus eblingi, a new species of Halacaridae (Acari) from Andaman Islands (Indian Ocean). Journal of the Bombay Natural History Society, 88 (1), 88-92.

Chatterjee, T. (1992). Copidonathus krantzi, a new species of Halacaridae (Acari) from Nicobar Islands (Indian Ocean). Journal of the Bombay Natural History Society, 89 (1), 106-109.

Chatterjee, T. (1995). Occurrence of Copidognathus longispinus Bartsch \& Illiffi 1985 (Halacaridae: Acari) from Indian Ocean. Journal of the Marine Biological Association of India, 37, 31-34.

Chatterjee, T. (1996). Record of Copidognathus tamaeus Bartsch (Halacaridae: Acari) from Indian Ocean. Journal of the Marine Biological Association of India, 38, 141-143.

Chatterjee, T. (1997). A new species, Copidognathus pseudosidellus (Halacaridae: Acari) from the Andaman Islands. Journal of the Andaman Science Association, 13 (1\&2), 94-98.

Chatterjee, T. (1999a). First record of Copidognathus faubeli Bartsch (Halacaridae: Acari) from the Indian Ocean. Journal of the Bombay Natural History Society, 96 (1), 170-171.

Chatterjee, T. (1999b). A new species of Copidognathus (Halacaridae: Acari) from Andaman Islands. Journal of the Bombay Natural History Society, 96 (3), 447-450 [ERRATUM Journal of the Bombay Natural History Society (2000), 1 (97)]. 
Chatterjee, T. (2000). Two new species of Copidognathus (Halacaridae: Acari) from Kerala. Journal of the Bombay Natural History Society, 97 (2), 235-239.

Chatterjee, T. (2015). Scanning electron microscopic observations of Copidognathus balakrishnani Chatterjee (Acari: Halacaridae) with notes on species of the Copidognathus balakrishnani group. Acta Biologica, 22, 213-222.

Chatterjee, T., Annapurna, C. (2002). Copidognathus waltairensis, a new species of Halacaridae (Acari) from Visakhapatnam coast (Bay of Bengal). Proceedings of Andhra Pradesh Academi of Sciences, $6(1), 69-72$.

Chatterjee, T., Annapurna, C. (2003). Additional information on three species of Halacaridae (Acari) from India. Journal of Acquatic Biology, 18 (2), 51-54.

Chatterjee, T., Annapurna, C., Chang, C.Y. (2003). A new species of Copidognathus (Halacaridae: Acari) from India. Korean Journal of Biological Science, 7, 283-287.

Chatterjee, T., Annapurna, C., Chang, C.Y. (2004). A new species of the Copidognathus tricorneatus group (Acari: Halacaridae) from India. Hydrobiologia, 515, 75-78.

Chatterjee, T., Chang, C.Y. (2004). Two new Copidognathus halacarids (Acari: Halacaridae) from Mumbai coast of India (the Arabian Sea). Italian Journal of Zoology, 71, 265-269.

Chatterjee, T., De Troch, M. (2003). Copidognathus andamanensis, a new marine Halacaridae (Acari) from Andaman Island (India). Bulletin De L' Institut Royal des Sciences Naturelles de Belgique, Belgium, Entomologie, 73, 51-56.

Chatterjee, T., Guru, B.C. (2011). Scanning electron microscopic observations of Copidognathus arabicus Chatterjee \& Chang (Acari, Halacaridae) and notes on the distribution of the Copidognathus bairdi group sensu lato in the Indian Ocean. Natura Montenegrina, 10 (4), 425-434.

Chatterjee, T., Guru, B.C. (2013). New records of halacarid mites (Acari: Halacaridae) from the Andaman and Nicobar Islands, India. Acta Biologica, 20, 5-15.

Chatterjee, T., Sarma, A. L. N. (1993). Occurrence of Copidognathus sideus Bartsch 1982 (Halacaridae: Acari) from Indian Ocean region. Journal of the Bombay Natural History Society, 90 (2), 304-308.

Newell, I.M. (1947). A systematic and ecological study of the Halacaridae of eastern North America. Bulletin of the Bingham Oceanographic Collection, 10, 1-232.

Newell, I.M. (1950). New species of Copidognathus (Acari, Halacaridae) from the Aleutians. American Museum Novitates, 1476, 1-9.

Otto, J.C. (2001). Two new species of the Copidognathus tricorneatus group (Arachnida: Acari: Halacaridae) from the Great Barrier Reef Marine Park. Species Diversity, 6, 347-354.

Pepato, A.R., Tiago, C.G. (2005). New species and new occurrence of Copidognathus (Acari, Halacaridae) from the northern littoral zone of Sao Paulo State (Brazil). Zootaxa, 1083, 1-35.

Proches, S. (2002). New species of Copidognathinae (Acari: Halacaridae) from southern Africa. Journal of Natural History, 36, 999-1007.

Sarma, A.L.N., Chatterjee, T. (1991). Occurrence of Copidognathus hartwigi Bartsch (Halacaridae: Acari) from Indian ocean. Journal of the Bombay Natural History Society, 88 (2), 300-302.

Trouessart, E. (1894). Note sur les acariens marins (Halacaridae) dragués par M.P. Hallez dans le Pas-deCalais. Revue Biologique du Nord de la France, 6, 154-184.

Viets, K. (1928). Wassermilben aus dem Schwarzen Meer, dem Kaspischen Meer und dem Aral-See. Abhandlungen. Naturwissenschaftlicher Verein zu Bremen, 27, 47-80.

Viets, K. (1936). Zoologische Ergebnisse einer Reise nach Bonaire, Curaçao und Aruba im Jahre 1930. No. 18. Halacariden aus Westindien. Zoologische Jahrbücher, Abteilung für Systematik, Ökologie und Geographie der Tiere, 67, 389-424. 
Viets, K. (1938). Über eine neue Art von Meeresmilben, Copidognathopsis tricorneata Lohmann (Halacaridae, Acari). Zoologischer Anzeiger, 122, 127-132.

Voinov, D.N. (1896). Halacarus Trouessarti. Nouvelle espèce d'Halacaridae de la Méditerranée. Bulletin de la Société Zoologique de France, 21, 128-129.

Cite as: Chatterjee, T. (2018). New record of Copidognathus andhraensis (Acari: Halacaridae) from the west coast of India, Arabian Sea. Acta Biologica, 25, 123-129. DOI: 10.18276/ab.2018.25-10. 